\title{
SEISMOLOG̣IJAS PRAKTISKĀ NOZĪME ZEMAS SEISMISKĀS AKTIVITĀTES APGABALOS, RĪGAS PILSĒTAS PIEMĒRS
}

\author{
Valērijs N̦ikulins \\ Latvijas Universitāte, e-pasts: valerijs.nikulins@lu.Iv; \\ Latvijas Vides, ǵeoloǵijas un meteoroloǵijas centrs, e-pasts: valerijs.nikulins@lvgmc.lv
}

Anotācija. Seismoloǵiskās metodes, piemēram, seismiskā mikrorajonēšana, pieḷaujamā vibrācijas līmeņa novērtējums, grunts dinamisko īpašību novērtējums transporta maǵistrāḷu rajonā u.c., var tikt praktiski izmantotas rajonos ar zemu seismiskumu.

Atslēgas vārdi: seismiskā mikrorajonēšana, tehnogēnā vibrācija, grunts dinamiskās īpašības.

\section{Ievads}

Latvijas teritorija atbilst rajonam ar l̦oti zemu seismiskumu. Latvijā maksimālais paātrinājums devona cietajām gruntīm (A tips) ir 0,013 g, kur g - brīvās krišanas pāātrinājums (Nikulin 2011). Tomēr uz irdeno kvartāra nogulumu virsmas paātrinājums var pārsniegt 0,05 g (Ṇikuḷins 2009b). Tādēḷ, ceḷot augstceltṇu dzīvojamās ēkas, nozīmīgas inženiertehniskās un ekologiski bīstamas būves, ir nepieciešams n̦emt vērā Eurocode 8 rekomendācijas, tas nozīmē - atsevišķos gadījumos veikt seismisko mikrorajonēšanu (SMR). Pēc 2004. gada zemestrīces Kalininingradas apgabalā veikti vairāki SMR pētījumi (Алешин и др. 2014), kas rāda, ka seismoloǵiskā metode varētu būt lietderīga rajonos ar zemu seismisko aktivitāti. Šajā rakstā izskatītas seismoloǵijas metožu, piemēram, seismiskā mikrorajonēšana, pieļaujamā vibrācijas līmeṇa novērtējums no tehnogēniem avotiem, grunts dinamisko īpašību novērtējums transporta maǵistrāḷu rajonā u.c., lietošanas iespējas Latvijā, izmantojot Rīgas pilsētas piemēru.

\section{Priekšnoteikumi, materiāli un metodes}

Viens no pilsētu infrastruktūras objektu, ēku, būvju, transporta sistēmu seismiskās vai vibrācijas drošības faktoriem ir grunts labvēlīgie un stabili apstākḷi.

Latvijas, tai skaitā arī Rīgas, grunts apstākḷus raksturo pleistocēna un holocēna irdenās un ūdens piesātinātās gruntis, kuras pārklāj blīvos augšdevona pamatiežus. Seismiskās stiprības attiecība starp augstāk un zemāk iegulošiem nogulumiem būtiski ietekmē svārstību pastiprināšanos līdz 10 un vairāk reizēm. Seismiskās stiprības kontrasts rada labvēlīgus apstākḷus grunts rezonansei, ja grunts slāņa biezums sakrīt ar 1/4 seismiskā viḷna garuma. Lokālie seismoǵeoloǵiskie apstākḷi ir samērā main̄̄gi, par ko liecina satricinājuma palielinājums atsevišķos Latvijas rajonos (Kalnu ciems Saldus novadā, Dobeles pilsēta) pēc Kaḷininingradas zemestrīces (Nikulin 2005). Projektējot un ekspluatējot ēkas, būves un transporta maǵistrāles Latvijā ir nepieciešams ņemt vērā grunts nelabvēlīgos apstākḷus. Cikliski procesi ir papildus faktori, kas pastiprina vibrācijas sekas un var izraisīt deformācijas uzkrāšanos gruntīs, ēkās un būvēs. Šādu deformācijas piemēru ir samērā daudz (tramvaja, dzelzceḷa līnijas un šosejas).

Grunts atbalss modelēšanai tika izmantoti materiāli par grunts uzbūvi dziḷumā. Projekta PanGeo rezultāti tika izmantoti kā tektonisko kustību kvalitatīvs pierādījums. 


\section{Rezultāti}

1. piemērs

Tehnogēnās vibrācijas ietekmes tipisks gadījums, deformējot ēku, notika 2014. gada 30. jūlijā Mežciemā Rīgā. Celtniecības laukumā, dzenot pāḷus, notika mājas seguma betona plātnes nosēšanās. To izraisīja jau esošo plaisu palielināšanās augšstāva dzīvoklī no 2 mm līdz 3-4 cm. Vibrācijas ātrums šajā gadījumā var mainīties no 3,8 līdz $7,7 \mathrm{~mm} / \mathrm{s}$. Latvijā nav ieviesti ēkām un būvēm pieḷaujamo vibrācijas līmeni reglamentējoši normatīivie dokumenti. Saskaṇā ar Vācijas normatīvu DIN 4150-3:1999, novērtētais augšējais vibrācijas līmenis $7,7 \mathrm{~mm} / \mathrm{s}$ pārsniedz pieļaujamās vibrācijas līmeni $5 \mathrm{~mm} / \mathrm{s}$ ìslaicīgos vibrācijas apstākḷos. Acīmredzami, ka, neṇemot vērā tehnogēnā avota izraisīto vibrāciju celtniecības laukumā, īpaši dzenot pāḷs, irdenas un apūdeņotas grunts apstākḷos, var rasties būves deformācijas, radot draudus cilvēkiem un ēku bojājumus.

\section{2. piemērs}

Īpašu interesi izraisa seismisko svārstību pastiprināšanās nozīmīgu inženiertehnisko objektu rajonos dažādu seismisko avotu iedarbības rezultātā. Grunts svārstību pastiprinājuma modelēšanai zem TEC-1 (Rīga) izmantots 61 m biezs trīs slāṇu griezums (381/1844. urb.), 2004. gada 21. septembra Kaḷiņingradas zemestrīces seismogramma (stacijā Molde, Norvēǵija), kā arī seismiskais troksnis, kas iegūts, nosakot vidējās mikroseismiskās svārstības no BAVSEN tīkla vairākām stacijām (N,ikuḷins 2009a).

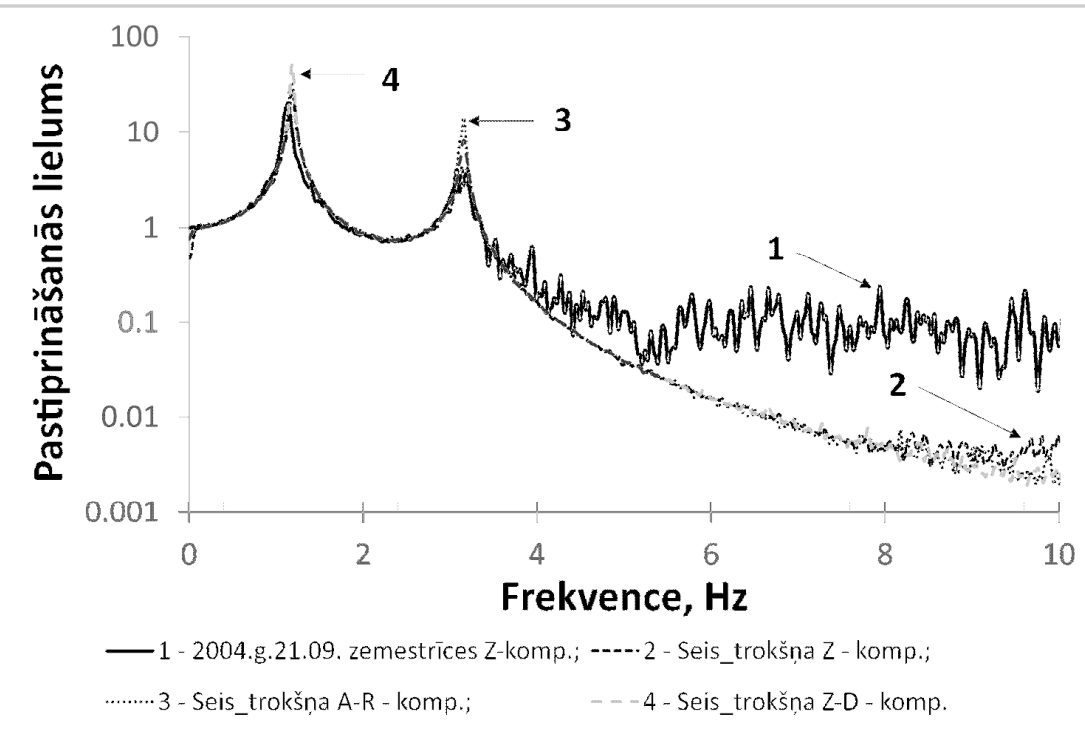

1. attēls. Grunts svārstību pastiprinājuma modelis TEC-1 (Rīga) rajonā Kalininingradas zemestrīces (21.09.2004.) seismisko viḷnu (1) un seismiskā trokšṇa (2-4) iedarbības rezultātā

Piezīme: Svārstību komponentes: Z-D - ziemeḷu - dienvidu virzienā; A-R - austrumu rietumu virzienā; $Z$ - vertikālā virzienā 
Neatkarīgi no dabiskā signāla avota (zemestrīce vai seismiskais troksnis) pastāv divas rezonanses frekvences $f_{1}$ un $f_{2}$, kurām noteikti atbilstoši pastiprinājuma koeficienti $A_{1}$ un $A_{2}$ (1. tabula).

1. tabula. Grunts pastiprinājuma parametri zem TEC-1 ēkām

\begin{tabular}{|c|c|c|c|c|}
\hline & Zemestrīce & \multicolumn{3}{|c|}{ Seismiskais troksnis } \\
\hline Parametrs & $Z-D$ & $Z$ & $Z-D$ & $A-R$ \\
\hline$f_{1}, \mathrm{~Hz}$ & 1,1 & 1,2 & 1,2 & 1,2 \\
\hline$A_{1}$ & 20,7 & 28,0 & 52,4 & 33,4 \\
\hline$f_{2}, \mathrm{~Hz}$ & 3,1 & 3,1 & 3,2 & 3,2 \\
\hline$A_{2}$ & 4,1 & 4,2 & 8,2 & 14,5 \\
\hline
\end{tabular}

Tādējādi ir lietderīgi veikt rekognoscēšanas seismisko izpēti pirms svarīgu inženiertehnisko objektu celtniecības laukuma izvēles vai jau esošo objektu monitoringu, vēl jo vairāk, ja tajos tiks izmantotas augstas precizitātes iekārtas un aparatūra, kas nepieḷauj noteikta vibrācijas līmeṇa pārsniegšanu.

\section{3. piemērs}

Rīgas rajona ǵeodinamiskos apstākḷus var raksturot kā sarežğìtus, jo pilsētas teritoriju šķērso Kaledonijas struktūrkompleksa tektoniskie lūzumi. Nozīmīgs ir jautājums par to tektonisko aktivitāti mūsdienās. Pēdējā laikā, no 2010. līdz 2013. gadam, ir iegūti pierādījumi šādai aktivitātei. Pirmkārt, satricinājums 2010. gada 22. novembrī, kuru sajuta Rīgā un Rīgas rajonā (Никулин 2011). Otrkārt, pēc tālizpētes metodes Persistent Scatterer Interferometry (PSI) rezultātiem projekta PanGeo ietvaros (Никулин 2013), Latvijā atklāti ǵeologiiskās bīstamības poligoni (G̣BP). G̣eologiskās bīstamības priekšnosacījums ir dziḷie, tektoniskie apstākḷi Rīgas G̣BP daḷā (10 gadījumos no 57). Novērojuma punktu pārvietošanās ātruma analīze, izmantojot PSI metodi, parādīja gradienta zonu klātbūtni tur, kur dzelzceḷa līnija Rīga - Jelgava šḳērso beznosaukuma tektonisko lūzumu (2. attēls). Lūzuma dažādās pusēs $76 \mathrm{~m}$ attālumā viens no otra atrodas divi PS punkti, kuri virzās pretējos virzienos ar ātrumu +13,8 mm/gadā un $11,6 \mathrm{~mm} /$ gadā.

Tādējādi ǵeodinamiski aktīvās teritorijās ir nepieciešama sistemātiska kontrole, lai novērstu grunts kustību izraisītas avārijas situācijas. Var lietot seismoloǵisko monitoringu, izmantojot lokālo novērojumu tīklu. Seismiskā metode dod iespēju novērtēt grunts dinamiskās īpašības. Šim nolūkam efektīvākā un operatīvākā ir spektrālo attiecību H/V metode, izmantojot mikroseismisko svārstību analīzi (Nakamura 1989). 

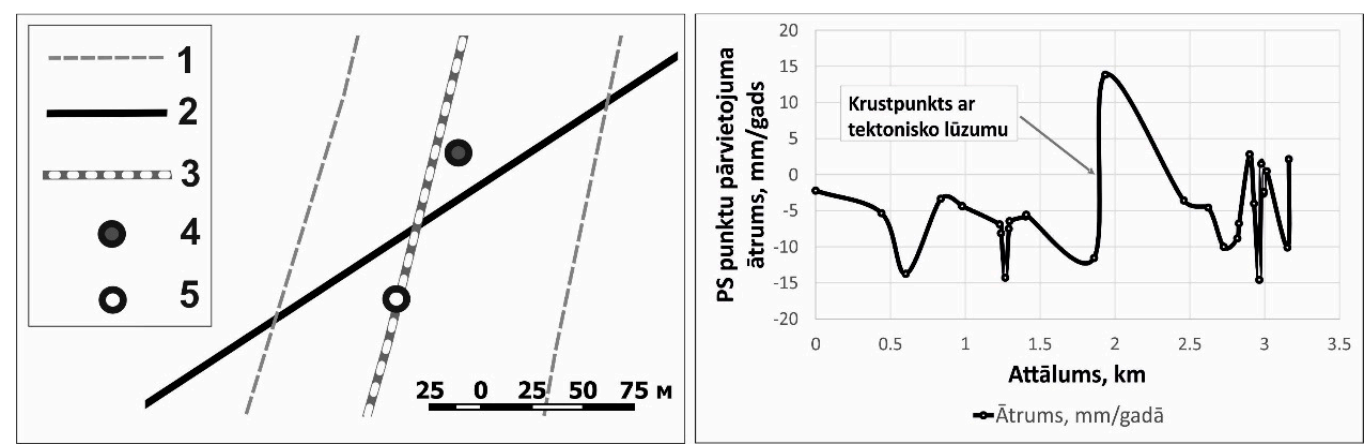

2. attêls. Tektoniskā lūzuma un dzelzcẹ̣a līnijas Rīga-Jelgava iecirkṇa izvietojuma shēma (pa kreisi) un $P S$ punktu pārvietošanās ātrums gar dzelzceḷu no Gaismas līdz Tĩrainei (pa labi)

Apzīmējumi: 1 - GBPP zonas kontūra; 2 - tektoniskais lūzums; 3 - dzelzcela līnija; PS punkti ar pārvietošanās àtrumu $+13.8 \mathrm{~mm} / \mathrm{gada}$ (4) un - $11.6 \mathrm{~mm} /$ gadā (5)

\section{Atsauces}

Nakamura, Y. (1989). Method for dynamic characteristics estimation of subsurface using microtremor on the ground surface. Quarterly report of RTRI, 30(1),. 25 - 33.

Nikulin, V. (2005). Estimation of seismic effects in Latvia from the Kaliningrad earthquake of September 21, 2004. Kaliningrad earthquake of September 21, 2004, Macroseismic data for near and mesoseismal zones. Kaliningrad earthquake September 21, 2004. Workshop materials. $30-31$.

Nikulin, V. (2011). Assessment of the seismic hazard in Latvia. Version of 2007 year. RTU zinātniskie raksti. Materiālzinātne un lietišķā ķīmija. Sērija 1, sēj. 24, 110 - 115.

N̦ikuḷins, V. (2009a). Baltijas virtuālais seismiskais tīkls un tā aprobēšanas iepriekšējie rezultāti. LU 67.zinātniskā konference. Geogräfija, geoloǵija, Vides zinātne. Referātu tēzes. 222 $-223$.

N̦ikuḷins, V. (2009b). Seismiskā efekta novērtējuma rezultāti kvartāra nogulumos Latvijā. LU 67.zinātniskā konference. Ģeogrāfija, geologiija, Vides zinātne. Referātu tēzes. 223 - 225.

Алешин, А.С., Аносов, Г.И., Бессараб, Ф.С., Дробиз, М.В., Дементьев, Ю.В., Погребченко, В.В., Рогаль, Л.А., Скворцов, А.Г., Царев, А.М., Чугаевич, В.Я. (2014). Сейсмическое микрорайонирование территории г. Калининграда. Инженерные изыскания, 9 - 10, $68-79$.

Никулин, В.Г. (2011). Сейсмические сотрясения 22 ноября 2010 года в Риге и Рижском районе. Актуальные вопросы мониторинга геологической среды $u$ безопасности урбанизированных территорий. Тезисы докладов 1-й международной конференции. БФУ им. И. Канта, 49 - 52.

Никулин, В. (2013). Зоны геологической опасности для Лиепаи и Риги на основе результатов дистанционного зондирования методом Persistent Scatterer Interferometry. Sabiedrība un kultūra. Liepājas Universitāte, XVI, 432 - 439.

\section{Summary}

The seismological method can have practical meaning in areas of low seismic activity, as shown by various examples. These methods include seismic micro-zonation, estimation of vibration levels, dynamic properties of soils for highways, etc. 